\title{
A method of comparing the wear resistance of various materials used for artificial teeth
}

\author{
Um método de comparação de resistência de desgaste de materiais usados para dentes artificiais
}

\author{
Claudia Maria Zarpelon SILVA' \\ José Virgílio de Paula EDUARDO' \\ Milton Edson MIRANDA ${ }^{1}$ \\ Roberta Tarkany BASTING ${ }^{2}$ \\ Karina Andrea Novaes OLIVIERI ${ }^{1}$
}

\section{ABSTRACT}

\section{Objective}

Abrasion resistance of three commercial brands of acrylic resin for artificial teeth, available on the domestic market (Biotone ${ }^{\circledR}$, Plus ${ }^{\circledR}$ and Vipi Dent Artiplus $\left.{ }^{\circledR}\right)$ was evaluated by a new methodology called "Pirassununga Method ".

\section{Methods}

The Manufacturers produced the maxillary central incisor-shaped incisal resin specimens $(n=27)$. These were embedded in chemically activated acrylic resin in an insulated metal matrix to fabricate test specimens, which were flattened on a lathe and refined manually with sandpaper. Wear testing was conducted in an experimental machine at the Vipi dental products factory. In the "Pirassununga Method" a polished metal sphere $4.8 \mathrm{~mm}$ in diameter, attached to a rotary device passes over the fixed specimens in programmable cycles, under $5 \mathrm{~N}$ pressure, using distilled water as lubricant. In each sample, the groove caused by abrasion, was analyzed in two ways: Readout under a microscope to determine the breadth and depth of the groove caused by the ball, and by laser roughness meter readout, which obtained a value Rt.

\section{Results}

The nonparametric Kruskal Wallis test showed no statistically significant difference between the medians of brands evaluated in the cycles performed $(p=0.936)$.

\section{Conclusion}

Artiplus ${ }^{\circledR}$ Brand showed a lower tendency to wear than commercial brands Biotone ${ }^{\circledR}$ and Plus ${ }^{\circledR}$ Vipi Dent, with the best performance shown for the IPN polymer.

Indexing terms: Acrylic resins. Artificial tooth. Polymer. Tooth wear.

\section{RESUMO}

\section{Objetivo}

Avaliar a resistência ao desgaste por abrasão de três marcas comerciais de dentes artificiais de resina acrílica disponíveis no mercado nacional $\left(\right.$ Biotone $^{\circledR}$, Vipi Dent Plus ${ }^{\circledR}$ e Artiplus ${ }^{\circledR}$ ) por meio de uma nova metodologia.

\section{Métodos}

Os corpos de prova foram produzidos pelos fabricantes, com resina incisal em forma de incisivos centrais superiores ( $n=27$ ). Esses dentes foram incluídos em resina acrílica ativada quimicamente dentro de uma matriz de metal isolada para confecção dos corpos de prova, e depois aplainados em torno mecânico e refinados com lixa d'agua manualmente. O ensaio do desgaste foi realizado em uma máquina experimental presente na fábrica de produtos odontológicos Vipi. No "Método Pirassununga" uma esfera metálica polida de 4,8 mm de diâmetro presa em um dispositivo que rotaciona, passa sobre os corpos de prova que estão fixos, em ciclos que podem ser programados, e tendo água destilada como lubrificante e pressão de $5 \mathrm{~N}$. O sulco provocado pela abrasão em cada corpo de prova foi analisado de duas maneiras: Leitura em microscópio para determinar a largura e a profundidade do sulco provocado pela esfera e rugosímetro de leitura a laser, do qual foi obtido o valor Rt.

\section{Resultados}

Por meio do teste não paramétrico de Kruskal Wallis observou-se que não houve diferença estatisticamente significante entre as medianas das marcas avaliadas nos ciclos realizados $(p=0,936)$.

\section{Conclusão}

Pode-se concluir que a marca comercial Artiplus ${ }^{\circledR}$ tem uma menor tendência ao desgaste do que as marcas comerciais Biotone ${ }^{\circledR}$ e Vipi Dent Plus $^{\circledR}$, evidenciando o melhor desempenho do polímero IPN.

Termos de indexação: Resinas acrílicas. Dente artificial. Polímeros. Desgaste dos dentes.

\footnotetext{
${ }^{1}$ Faculdade São Leopoldo Mandic, Curso de Odontologia, Programa de Pós-Graduação em Prótese Dentária. Rua José Rocha Junqueira, 13, 13045-755, Campinas, SP, Brasil. Correspondência para / Correspondence to: KAN OLIVIERI. E-mail: <karina_olivieri@hotmail.com>.

${ }^{2}$ Faculdade São Leopoldo Mandic, Curso de Odontologia, Programa de Pós-Graduação em Dentística. Campinas, SP, Brasil.
} 


\section{INTRODUCTION}

There was great advancement in the production of plastic teeth in the 1950s with the advent of crosslinking agents. Later, towards the end of the 1980s, cross-linked acrylic teeth with interpenetrated polymer links, characterizing IPN resin were developed, which represented the first change of impact on acrylic teeth. Technical advances have led to other manufacturers seeking excellence in the production of acrylic teeth with improved physical properties ${ }^{1-3}$.

According to Cornell et al. ${ }^{4}$, plastic materials for the manufacture of acrylic teeth appeared as from the 1940s. These were composed of an acrylic resin (polymethyl methacrylate), in its original form, formed by a chain link of various methyl methacrylate molecules in a straight line bonded by covalent bonds in an intramolecular fashion. The main advantage associated with these teeth was the presence of a chemical bond to the acrylic denture base ${ }^{1-5}$. Other advantages have been cited in several other studies, such as a natural appearance and being less friable than porcelain, less transmission of trauma to the residual ridge, natural feeling when in contact with the natural teeth as antagonists, reduced level of noise when chewing, ease of mounting the teeth when fabricating the denture, ease is making occlusal adjustment, ease of performing recontouring and polishing. However, the low resistance to wear was shown to be the main disadvantage. Some authors also consider the low color stability a disadvantage $\mathrm{e}^{1,2,6}$.

The wear of artificial teeth involves serious consequences for the completely or partially edentulous patient's oral health, particularly when the dental prostheses are used beyond their period of useful life. This is a concern to both the patient and dentist, because it will cause loss of vertical dimension, diminished masticatory efficiency, changes in dental relations, increase in horizontal load and associated sequelae, in addition to the possibility of causing parafunctional activities.

The aim of the present study was to evaluate the resistance to wear by abrasion of three commercial brands of acrylic resin artificial teeth available on the Brazilian market, by means of a new methodology.

\section{METHODS}

To conduct this test, 27 test specimens were fabricated, supplied by the manufacturers, as shown in Chart 1:
Chart 1. Test Specimens, Brand Name, Manufacturer and Chemical Composition

\begin{tabular}{|c|c|c|c|}
\hline $\begin{array}{l}\text { Number } \\
\text { of test } \\
\text { specimens }\end{array}$ & $\begin{array}{l}\text { Brand } \\
\text { Name }\end{array}$ & Manufacturer & $\begin{array}{l}\text { Chemical } \\
\text { Composition }\end{array}$ \\
\hline 9 & Artiplus $^{\circledR}$ & $\begin{array}{l}\text { Dentsply Indústria } \\
\text { e Comércio Ltda., } \\
\text { Petrópolis, RJ. Brazil. }\end{array}$ & $\begin{array}{c}\text { IPM Polymer } \\
\text { (Interpenetrated } \\
\text { Polymer Network) }\end{array}$ \\
\hline 9 & Biotone $^{\circledR}$ & $\begin{array}{l}\text { Dentsply Indústria } \\
\text { e Comércio Ltda., } \\
\text { Petrópolis, RJ. Brazil. }\end{array}$ & $\begin{array}{l}\text { PMMA Resin } \\
\text { Cross-linked } \\
\text { (Polymethyl } \\
\text { methacrylate) }\end{array}$ \\
\hline 9 & $\begin{array}{l}\text { Vipi Dent } \\
\text { Plus }^{\circledR}\end{array}$ & $\begin{array}{l}\text { Dental Vipi Ltda. } \\
\text { Ind. Com. Imp. e } \\
\text { Exp. de Produtos } \\
\text { Odontológicos, } \\
\text { Pirassununga, SP, } \\
\text { Brazil. }\end{array}$ & $\begin{array}{c}\text { PMMA Resin } \\
\text { (Polymethyl } \\
\text { methacrylate) and } \\
\text { EDMA (Polymerized } \\
\text { Ethylene Glycol } \\
\text { Dimethacrylate) } \\
\text { Cross-linked }\end{array}$ \\
\hline
\end{tabular}

The test specimens were produced by the manufacturers, using incisal resin in the shape of maxillary central incisors, maintaining the chemical composition of each origin. The commercial stock teeth, the incisal resin layer thickness ranges from 1.2 to $1.5 \mathrm{~mm}$. For this study, teeth were produced of incisal resin only, so that during the flattening process, the thickness of this resin would not be short of the thickness observed in the stock teeth. In addition, the shape of the maxillary central incisor was used, as this is a tooth with a flat morphology; that is, its anatomy facilitates flattening during the test, in spite of the most significant wear being clinically observed in posterior teeth ${ }^{3-4}$.

So that all the test specimens would be identical, they were all produce in a single matrix supplied by the collaborating company Vipi (Dental Vipi Ltda. Ind. Com. Imp. e Exp. de Produtos Odontológicos, Pirassununga, SP), with a single pressing of incisal resin, followed by the polymerization process of each manufacturer.

During manufacture of these teeth, a coloring agent was added to differentiate the manufacturers, with a blue tone added to the Artiplus ${ }^{\circledR}$ and Biotone ${ }^{\circledR}$ samples, and red in those of Vipi Dent Plus ${ }^{\circledR}$. This coloring agent (Ultramar, Clariant) was incorporated into the PPMA before pressing.

A metal matrix with ten rectangular cavities measuring $1.5 \mathrm{~cm} \times 2 \mathrm{~cm}$ was insulated with an insulator for acrylic resin (Cel-Lac, S.S.White Artigos Dentários, Rio de Janeiro, RJ, Brazil) and filled with colorless chemically activated acrylic resin (Jet, Artigos Odontológicos Clássico, São Paulo, Brazil).

In the plastic phase, the teeth manufactured were seated on this resin, with the palatine surface in contact with the colorless resin (Figure 1). After polymerization of the acrylic resin, a bloc was obtained, to which the fabricated tooth was adhered. The size of this block was designed so that it would fit perfectly to the wear machine that was used in the test. 


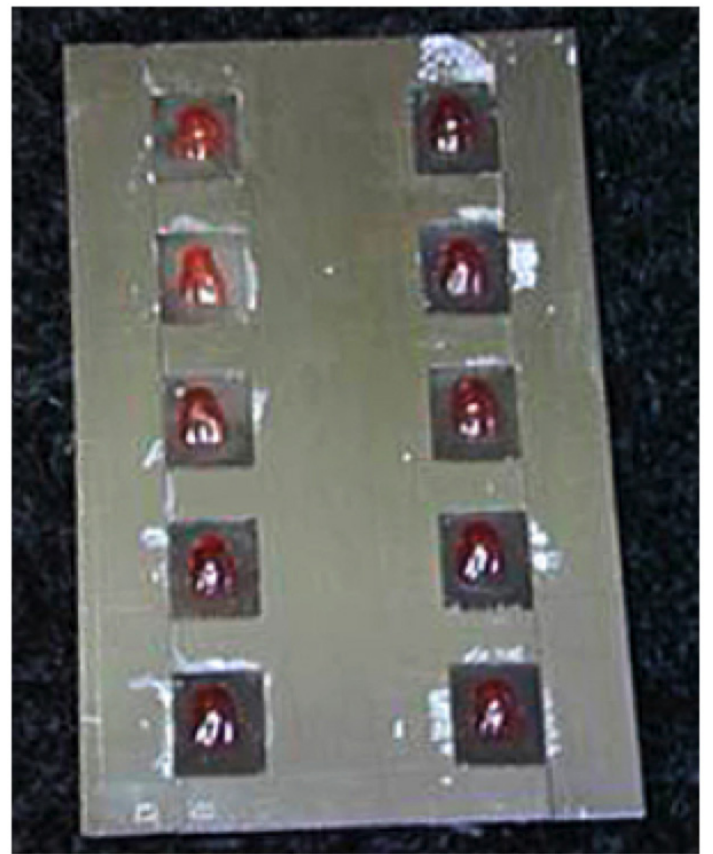

Figure 1. Metal matrix with acrylic resin and teeth in position.

The test specimens ere then removed from the metal matrix and one by one, they were flattened on a mechanical lathe and manually refined water abrasive paper grit 00 .

In groups of nine, the samples were placed on a metal device which was then coupled to the wear machine.

The test of wear by abrasion was performed in an experimental machine at the dental products factory Vipi (Dental Vipi Ltda. Ind. Com. Imp. e Exp. de Produtos Odontológicos, Pirassununga, SP, Brazil). In the method denominated "Pirassununga Method", a polished metal sphere $4.8 \mathrm{~mm}$ in diameter, fixed to a rotating device, passes over the fixed test specimens in cycles, which may be programmed in counter-gyrations (Figure 2), with distilled water as lubricant.

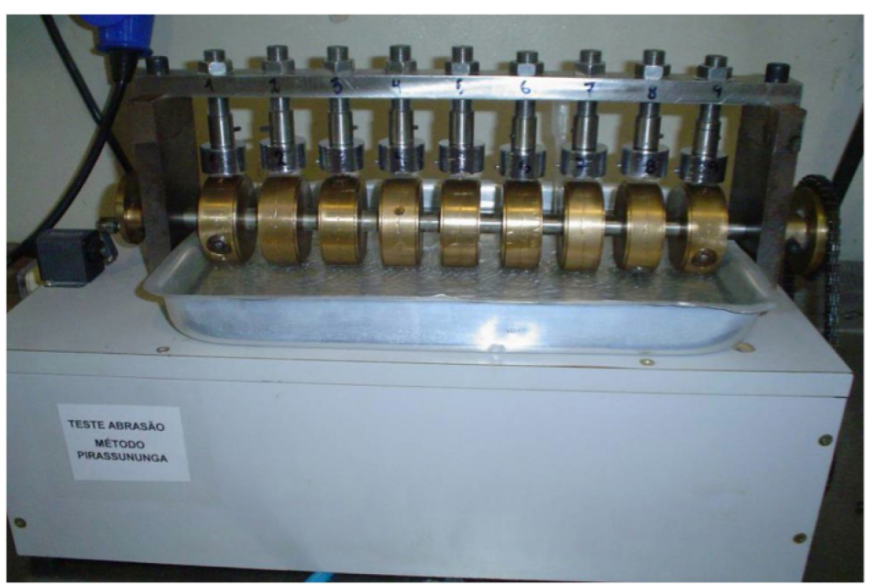

Figure 2. Test machine - Pirassununga Method. Note the receptacle with distilled water used as lubricant.
The rotational movement of the machine is at a constant speed of $18 \mathrm{~m} / \mathrm{min}$, with a pressure of $5 \mathrm{~N}$, also constant, on the sphere. This movement thus causes a groove in the test specimens. As this was an experimental study (without references to the use of this method in the literature) tests were performed with a lower number of cycles ( such as 1000, 2000 and 5000 cycles, however, the results for 1000 cycles were shown to be insignificant, and were therefore discarded ${ }^{5-6}$.

The groove caused by abrasion in each of the specimens was analyzed in two ways, for comparison of the results: a) readout under optical microscope: the test specimens were examined under a Nikon optical microscope at 40x magnification (Nikon lens 4/0.10) to determine the width of the groove caused by the sphere. By noting the width of the groove caused, and having prior knowledge of the thickness of the sphere, the depth of the groove cause was determined. This method of examining the wear groove is proposed by the "Pirassununga Method", and was conducted at the Vipi factory in Pirassununga (SP); b) laser rugosimeter readout: a conventional rugosimeter was tested and imprecise results were obtained. Therefore, a laser rugosimeter readout was used at the University of São Paulo - São Carlos Campus. The test specimens were positioned in such a manner that the laser sensor would perform the readout of the wear groove. The wavelength Rt (sum of the maximum height Yp of the curve with maximum depth $Y v$, both from the midline) was obtained in three readouts for each specimen, to obtain a mean value.

The results obtained were submitted to the analysis of variance (ONE-WAY ANOVA).

To summarize the information of the quantitative variables (width, depth and Rt), measures central tendency and measures of the dispersion of a set of measurements were used $^{7}$. As the measure of central tendency, the option was to use the median, since it is a robust measure that indicates the central position of a set of data without being affected by possible extreme values. The 1st and 3 rd quartiles were also used to indicate the values that left $25 \%$ and $75 \%$. respectively, of the observations below these values. As the dispersion measure, the amplitude of the set of observations represented by the minimum and maximum values was used.

Comparison among the medians was performed by means of the Kruskal-Wallis non parametric test. Comparison of the measures among the cycles was performed by means of the Mann-Whitney non parametric test. 
For all statistical analysis the level of significance of $5 \%(a=0.05)$ was adopted; that is, the results that presented a $p$-value lower than $5 \% \quad(p<0.05)$ were considered statistically significant.

The data were saved in an EXCEL type spreadsheet, and statistical analyses were performed with the software program SPSS 12.0 for Windows.

The present study was conducted in accordance with the ethical principles contained in the Helsinki Declaration (2000), and in compliance with the specific legislation of Brazil (Process \# 2007/033).

\section{RESULTS}

By means of the Kruskal-Wallis non parametric test, no statistically significant difference was observed between the medians of the brands evaluated in the cycles performed $(p=0.936)$ (Figure 3$)$.

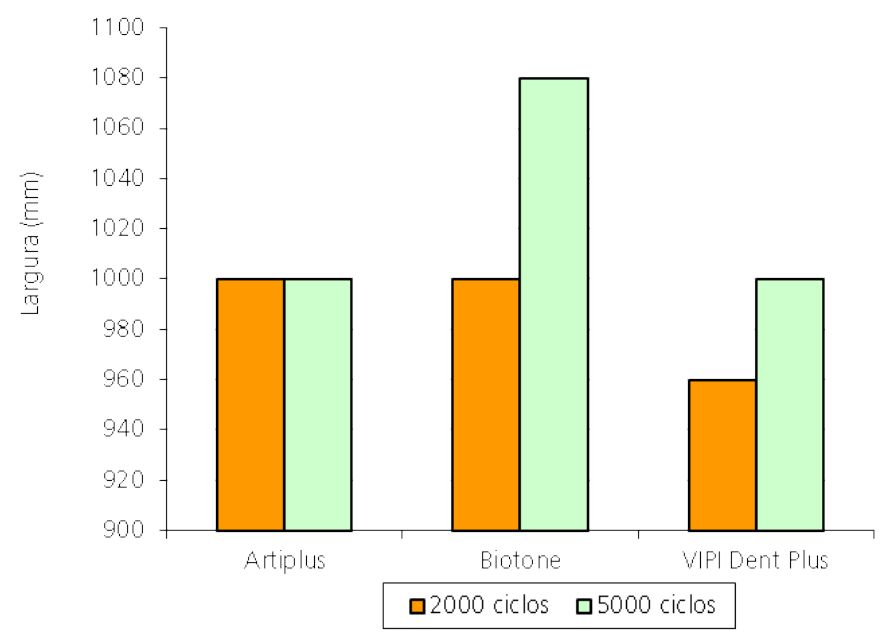

Figure 3. Distribution of median width according to commercial brand and cycle.

The Artiplus ${ }^{\circledR}$ brand presented the same median depth in the two cycles evaluated. Whereas, for the other brands, it could be observed that the median depth was higher at 5000 cycles when compared with the value observed at 2000 cycles. In spite of this variation observed descriptively, the Kruskal-Wallis test presented no statistically significant difference $(p=0.936)$; that is, the three brands evaluated did not differ in terms of depth (Figure 4).

Whereas, at 5000 cycles, it could be observed that the Artiplus ${ }^{\circledR}$ brand was the one that presented the highest median Rt. Furthermore, it was found that for the Vipi Dent Plus ${ }^{\circledR}$ brand, the median Rt at 2000 cycles presented a higher value than that presented at 5000 cycles (Figure 5).

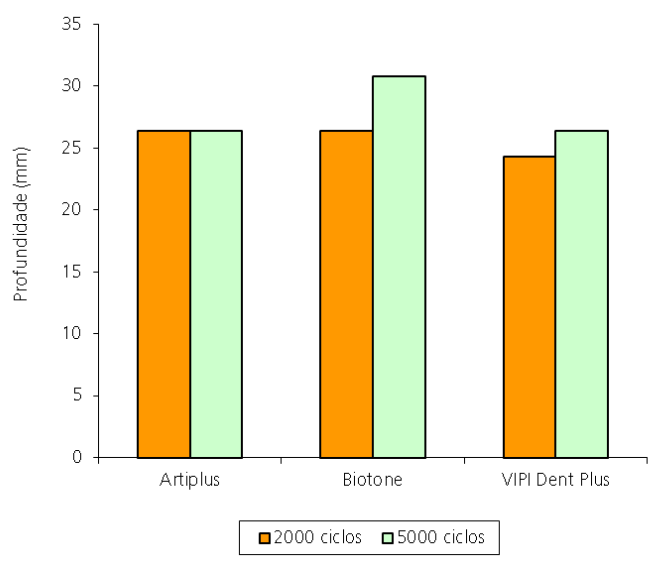

Figure 4. Distribution of median depth according to commercial brand and cycle.

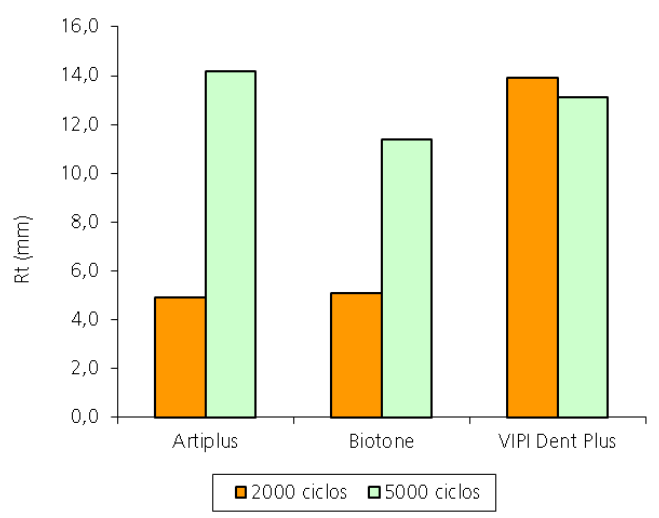

Figure 5. Distribution of median Rt according to commercial brand and cycle.

\section{DISCUSSION}

At present, acrylic resin teeth are the most indicated type of artificial teeth used in rehabilitations with partial or complete removable dental prostheses, in spite of presenting restrictions as regard color and wear over time of use ${ }^{2}$.

The present study was conducted using equipment belonging to the collaborating company Vipi (Dental Vipi Ltda. Ind. Com. Imp. e Exp. de Produtos Odontológicos, Pirassununga, SP, Brazil) by means of a new experimental methodology denominated the "Pirassununga Method". Therefore, no similar methodology was found in the literature.

Various methodologies have been proposed for evaluating the development of the pattern of wear in vivo $^{5,8-16}$ or in vitro ${ }^{3,4,17-23}$ of polymer artificial teeth, since the pioneering study of Beall ${ }^{5}$, up until recently, in the study of Reis ${ }^{23}$, reflecting the lack of standardization of clinical models and laboratory designs used, and making 
it difficult to compare the results available. Therefore, the development of a standard and reproducible machine suggested in the study of Whitman et al. ${ }^{2}$ was shown to be pertinent, because the only means of comparison of the results consisted of the listing of the tested materials in each study. This made the numerical comparison unfeasible because of the discrepancies in the findings obtained according to the method of evaluation, Lindquist et al., ${ }^{13}$.

As in this study, the majority of studies about the mechanical properties of artificial teeth are carried out by means of evaluating the wear index $4,5,9,17-18,24-27$. Other studies have sought to associate the mechanical properties of dental materials of which these products are composed 2,3,15,22-23.

The new methodology, denominated the "Pirassununga Method" proposed to evaluate the wear of a surface by means of readouts of the worn surface under a microscope, associated with readouts by conventional methods such as use of laser rugosimeter readout.

Firstly, the test specimens were produced with incisal resin, since the wear in the oral cavity begins on this surface. Raptis et al., ${ }^{27}$ in their study, confirmed that incisal resin is less susceptible to wear than the dentin of the acrylic tooth, suggesting a higher degree of resistance to wear.

The shape of the maxillary central incisors of the test specimens produced distinguish them from other studies $3,14,17-18$, in spite of the higher degree of wear in vivo being observed in the posterior teeth of the Complete Dental Prosthesis, causing loss of vertical dimension. However, in this case, maxillary central incisors were used, because they are teeth with a flatter morphology, which was better suited to the type of test performed.

In this study, the test was performed with a lower number of cycles (maximum of 5000 cycles), differing from the studies of other authors $4,20,22-23,25$. On the other hand, Khan et al. ${ }^{17}$ worked with only 500 cycles in their tests. Our justification for working with tests of up to 5000 cycles is due to the fact that this was an experimental methodology. The results observed with 1000 cycles were shown to be statistically insignificant, and were discarded.

With 2000 or 5000 cycles, statistically insignificant results were obtained for the three commercial brands of acrylic teeth evaluated, with regard to the width and depth of the groove of wear evaluated under a microscope (after 2000 cycles $p=0.936$ and $p=0.978$, after 5000 cycles $p=0.978$ and $p=0.679$ respectively).

It was only for the wavelength Rt that significant results were found between the commercial brands evaluated after 2000 cycles ( $p=0.032)$, with the median Rt of Vipi Dent Plus ${ }^{\circledR}$ being higher than the value observed for the Artiplus $^{\circledast}$ and Biotone ${ }^{\circledast}$ brands $(p=0.024)$. The Artiplus $^{\circledR}$ and Biotone ${ }^{\circledR}$ did not differ in terms of Rt after 2000 cycles ( $p>0.999$ ). This suggests that the readout of the groove of wear by a laser rugosimeter readout was more faithful than the readout observed under the microscope, since the latter is examiner-dependent. For 5000 cycles significant difference in the median of the wavelength Rt was also observed between the brands evaluated ( $p=0.004$ ), suggesting that the commercial brand Artiplus ${ }^{\circledR}$ had a lower tendency to wear among the brands tested in this study.

\section{CONCLUSION}

According to the methodology used, the commercial brand Artiplus ${ }^{\circledR}$ had a lower tendency to wear than the commercial brands Biotone ${ }^{\circledR}$ and Vipi Dent Plus ${ }^{\circledR}$, showing evidence of the better performance of the IPN polymer.

\section{REFERENCES}

1. Appelbaum M. Theories of posterior tooth selection: porcelain versus acrylic. Dent Clin North Am. 1984;28(2):299-306.

2. Whitman DJ, McKinney JE, Hinman RW, Hesby RA, Pelleu Junior $G B$. In vitro wear rates of three types of commercial denture tooth materials. J Prosthet Dent. 1987;57(2):243-6. doi: 10.1016/0022-3913(87)90154-5

3. Abe $Y$, Sato $Y$, Akagawa $Y$, Ohkawa $S$. An in vitro study of highstrength resin posterior denture tooth wear. Int J Prosthodont. 1997:10(1):28-34

4. Cornell JA, Jordan JS, Ellis S, Rose EE. A method of comparing the wear resistance of various materials used for artificial teeth. J Am Dent Assoc. 1957;54(5):608-14.

5. Beall JR. Wear of acrylic resin teeth. J Am Dent Assoc. 1943;30(1):252-6

6. Satoh Y, Nagai E, Maejima K, Azaki M, Matsuzu R, Matsuzu $M$, et al. Wear of denture teeth by use of metal plates. Part 2: Abrasive wear of posterior teeth. J Nihon Univ Sch Dent. 1992;34(1):16-27

7. Bussab WO, Morettin PA. Estatística básica. $5^{a}$ ed. São Paulo: Saraiva; 2003. 
8. Franks AST. A clinical appraisal of acrylic tooth wear. Dent Pract. 1962;12(5):149-53.

9. Harrison A, Huggett R. Measuring the rate of wear of artificial teeth in complete dentures. J Prosthet Dent. 1975;33(6):615-9.

10. Ogle RE, David LJ, Ortman HR. Clinical wear study of a new tooth material: part II. J Prosthet Dent. 1985;54(1):67-75.

11. Adams LP, Jooste $\mathrm{CH}$, Thomas CJ. An indirect in vivo method for quantification of wear of denture teeth. Dent Mater. 1989;5(1):31-4. doi: 10.1016/0109-5641(89)90089-4

12. Ekfeldt A, Oilo G. Wear mechanisms of resin and porcelain denture teeth. Acta Odontol Scand. 1989;47(6):391-9.

13. Lindquist TJ, Ogle RE, Davis EL. Twelve-month results of a clinical wear study of three artificial tooth materials. J Prosthet Dent. 1995;74(2):156-61.

14. Adams LP, Jooste $\mathrm{CH}$, Thomas CJ, Harris AM. Biostereometric quantification of clinical denture tooth wear. J Oral Rehabil. 1996;23(10):667-74.

15. Jooste C, Geerts G, Adams L. Comparison of the clinical abrasion resistance of six commercially available denture teeth. J Prosthet Dent. 1997;77(1):23-7. doi: 10.1016/S0022-3913(97)70202-6

16. Ogle RE, Davis EL. Clinical wear study of three commercially available artificial tooth materials: thirty-six month results. J Prosthet Dent. 1998;79(2):145-51. doi: 10.1016/S00223913(98)70208-2

17. Khan Z, Morris JC, von Fraunhofer JA. Wear of anatomic acrylic resin denture teeth. J Prosthet Dent. 1985;53(4):550-1.

18. von Fraunhofer JA, Razavi R, Khan Z. Wear characteristics of high-strength denture teeth. J Prosthet Dent. 1988;59(2):173-5.
19. Winkler S, Monasky GE, Kwok J. Laboratory wear investigation of resin posterior denture teeth. J Prosthet Dent. 1992;67(6):8124. doi: 10.1016/0022-3913(92)90590-7

20. Hirano S, May KB, Wagner WC, Hacker $\mathrm{CH}$. In vitro wear of resin denture teeth. J Prosthet Dent. 1998;79(2):152-5. doi: 10.1016/ S0022-3913(98)70209-4

21. Abe $Y$, Sato $Y$, Taji T, Akagawa $Y$, Lambrechts $P$, Vanherle $G$. An in vitro wear study of posterior denture tooth materials on human enamel. J Oral Rehabil. 2001;28(5):407-12. doi: 10.1046/j.13652842.2001.00670.x

22. Suzuki S. In vitro wear of nano-composite denture teeth J Prosthodont. 2004;13(4):238-43. doi: 10.1111/j.1532849X.2004.04043.x

23. Reis KR. Análise da microdureza superficial Knoop e da resistência ao desgaste de dentes artificiais de resina acrílica [dissertação]. Bauru: Universidade de São Paulo; 2005.

25. Stober T, Lutz T, Gilde H, Rammelsberg P. Wear of resin denture teeth by two-body contact. Dent Mater. 2006;22(3):243-9. doi: 10.1016/j.dental.2005.03.009

26. Ohlmann B, Rohstock K, Kugler J, Gilde H, Nat R, Dreyhaupt J, et al. Influences on clinical wear of acrylic denture teeth: a pilot study. Int J Prosthodont. 2007;20(5):496-8.

27. Raptis CN, Powers JM, Fan PL. Frictional behavior and surface failure of acrylic denture teeth. J Dent Res. 1981;60(5):908-13. doi: 10.1177/00220345810600051001

Received on: 26/11/2012

Final version resubmitted on: 9/8/2013

Approved on: 29/11/2013 